\title{
The past, present and future of euro area monetary-fiscal interactions
}

\section{Karl Whelan $^{1}$ (D)}

Accepted: 14 February 2022 / Published online: 1 March 2022

(C) The Author(s) 2022

\begin{abstract}
The EU's Treaties were designed to limit the interaction between fiscal and monetary policies. However, over the last decade, the introduction of the ECB's Outright Monetary Transactions (OMT) programme and its sovereign bond purchase programmes has created some strong linkages between monetary and fiscal policies in the Eurosystem. The ECB's monetary policies have improved fiscal debt sustainability and reduced the probability of sovereign default. However, there may need to be limits to the ECB's purchases of sovereign bonds. This paper discusses the interactions between fiscal and monetary policies in the euro area and describes how the arguments raised by the European Court of Justice in the Weiss and Gauweiler cases suggest there may be hard limits on the size of the Eurosystem's sovereign bond holdings. These limits may undermine the positive impact of the OMT announcement and force the ECB into some difficult choices in the coming years.
\end{abstract}

Keywords Fiscal policy $\cdot$ Monetary policy $\cdot$ European Central Bank $\cdot$ Monetary financing

\section{Introduction}

The potential for interactions between fiscal and monetary policies was an important consideration for the designers of the economic policy architecture of the euro area in the Maastricht Treaty. The 'founding fathers' were concerned about the possibility of 'fiscal dominance' affecting the new currency. These concerns were understandable. There are many historical examples of countries with high public debt levels seeking to reduce the burden of this debt via policies such as financial

Karl Whelan

karl.whelan@ucd.ie

1 University College Dublin, Dublin, Ireland 
repression, exchange rate devaluation, central bank purchases of sovereign bonds and loose monetary policies. By engineering high inflation, the latter policies can at least partially help to 'inflate away' a large public debt burden. ${ }^{1}$ Indeed, during the decades that preceded the introduction of the euro, participant countries in the European Monetary System that had higher public debt levels tended to have systematically higher inflation rates.

For this reason, the Maastricht Treaty contained several safeguards to prevent fiscal problems from undermining the euro and to separate the formulation of fiscal and monetary policies. An excessive deficit procedure was introduced, policed by the European Commission. The ECB was set up to be a highly independent organisation with price stability as its primary objective. Consequently, it was banned from providing monetary financing to states.

Despite these initial intentions, there are now a number of important interactions between fiscal and monetary policy in the euro area. Mario Draghi's 'whatever it takes' speech in 2012, followed by the announcement of the Outright Monetary Transactions (OMT) programme, had a profound influence on euro area sovereign debt markets, with markets coming to see the ECB as a 'sovereign bond buyer of last resort'. Subsequently, the ECB's asset purchase programmes saw the Eurosystem acquire a huge portfolio of euro area sovereign bonds. The introduction of the Pandemic Emergency Purchase Programme (PEPP) in 2020 meant a further ratchet up in these holdings.

This paper discusses the evolution of fiscal-monetary interactions in the euro area and evaluates the implications of the monetary financing prohibition for future ECB policies, focusing in particular on the views of the European Court of Justice (ECJ) as expressed in the Gauweiler judgement on OMT and the Weiss judgement on sovereign bond purchases by the Eurosystem. The focus is on reviewing the evidence and exploring the relevant legal issues rather than on presenting a statistical analysis.

The paper is structured as follows. Section 2 describes the treatment of fiscal policy issues in the EU's Treaties and the perception of sovereign risk prior to the founding of the euro and during its first years. Section 3 discusses the events that led to the announcement of the OMT programme and its implications for the interaction between fiscal and monetary policies. Section 4 discusses the Eurosystem's sovereign bond purchases and their implications for fiscal policy. Section 5 describes the ECJ's interpretation of the monetary financing clause in the Weiss and Gauweiler cases and its implications for the ECB. Finally, Section 6 previews future developments in this area. It argues that the ECJ may at some point require strict limits on the share of sovereign debt owned by the Eurosystem and describes how this may require the ECB to choose between maintaining its sovereign bond holdings and keeping space available to implement OMT.

\footnotetext{
1 See Reinhart et al. (2015) and Reinhart and Sbrancia (2015) for evidence on how high public debt burdens were managed in the past.
} 


\section{The Treaty's safeguards and the early years of the euro}

In this section, we discuss the Maastricht Treaty's provisions relating to fiscal-monetary interactions and how fiscal and monetary policy interacted in the early years of the euro.

\subsection{The safeguards}

The Maastricht Treaty had several elements designed to reduce pressures on monetary union caused by high levels of public debt. A central plank of the Treaty was the Stability and Growth Pact which features an excessive deficit procedure incorporating reference values of $60 \%$ for the debt to GDP ratio and $3 \%$ for the deficit to GDP ratio. Member states were required to adjust their debt and deficit levels towards these reference values, with states being subject to multilateral surveillance led by the European Commission.

Another area where fiscal issues were mentioned was the article commonly known as the 'no-bailout clause' (Article 125 of the current Treaty on the Functioning of the European Union, TFEU). However, the clause does not rule out bailouts in the sense of member states making loans to another member to allow them to pay off other creditors. Instead, it merely rules out the Union or the member states 'becoming liable for or assuming the commitments of' other states, which is not how bailouts usually work. Rather than a no-bailout clause, the motivation for the clause seems more likely to have been the avoidance of a federalisation of the existing stock of national debts.

In relation to monetary policy, Article 130 of TFEU established strong operational independence for the ECB and national central banks (NCBs) and Article 123 introduced a prohibition on monetary financing. Again, however, this clause was not as broad as it could have been. While the article prohibits the ECB or national central banks from providing credit facilities to government and rules out the direct purchases of sovereign bonds from governments, it does not rule out purchases of the sovereign bonds of member states on secondary markets.

There were, of course, good reasons to allow secondary market purchases of sovereign bonds. The Treaty's authors would not have wanted to rule out standard monetary operations such as open market operations in which a central bank purchases a sovereign bond. This is the classic textbook example of monetary policy. Repurchase agreements, in which NCBs provide credit to banks collateralised by temporary ownership of sovereign bonds by the NCB, have also been a key element of the ECB's monetary policy operations. But does the Treaty's acceptance of the legality of indirect sovereign bond purchases mean there are no limits on this activity? Ultimately, what matters is the ECJ's interpretation of Article 123 and, as we discuss in Section 5 below, their position on this issue is nuanced. 


\subsection{Sovereign default risk and the early years of the euro}

One implication of the Maastricht Treaty's tough stance on public debt was that euro area members whose public finances became unsustainable would have to go through a sovereign default. Even countries with modest debt burdens typically need a significant level of primary debt issuance each year to roll over maturing debts as well as funding any additional fiscal deficit. Many sovereign bonds come with cross acceleration clauses, so failure to roll over any previous debt can lead to repayment claims from other creditors, triggering the need for a full sovereign debt restructuring.

Against this background of large ongoing funding needs, the probability of default is particularly heightened by the absence of a central bank 'safety net' for governments, a possibility that was emphasised in the academic literature on sovereign default prior the euro's founding. For example, Cole and Kehoe (2000) illustrate how this situation implies the possibility of multiple 'self-fulfilling' sovereign default scenarios where investors do not wish to purchase sovereign bonds because they doubt whether other investors are willing to purchase them and the absence of buyers triggers a default. ${ }^{2}$

Despite this possibility, the large literature on EMU from the 1990s contained relatively few warnings about how the absence of a sovereign lender of last resort could undermine the euro. Two important exceptions were contributions from Charles Goodhart (1998) and Chris Sims (1999). Sims (1999) sketched out a scenario that conformed well with the euro crisis of 2010 to 2012.

If a country were in such distress that its interest rates rise substantially above those of other EMU members and that it thereby came to the brink of default, it seems very likely that it would leave the EMU and restart its independent monetary system. It would thereby revive the option of gentle, uniform, and partial default via inflationary finance and devaluation. If markets put some credence in this scenario, they will react to an EMU member's fiscal distress much the way they have historically reacted to a fragile commitment to a fixed exchange rate. Rising interest rates on debt will fuel speculation that drives the rates up even faster, increasing fiscal distress further, in a rapid spiral leading to crisis.

In general, however, there were few predictions during the 1990s that sovereign debt problems could cause severe difficulties for the euro. Instead, the debate about the euro largely focused on whether the candidate countries for EMU satisfied the criteria for an optimal currency area and on whether asymmetric shocks were going to become more or less likely once the euro was in place. ${ }^{3}$

With little historical experience of sovereign default in modern Europe and an ongoing period of relative macroeconomic stability known as 'the great moderation',

\footnotetext{
${ }^{2}$ See Cohen and Villemot (2015), Corsetti and Dedola (2016) and Aguiar et al. (2020) for more recent contributions to this literature.

3 See Whelan (2013) for a discussion of this literature.
} 


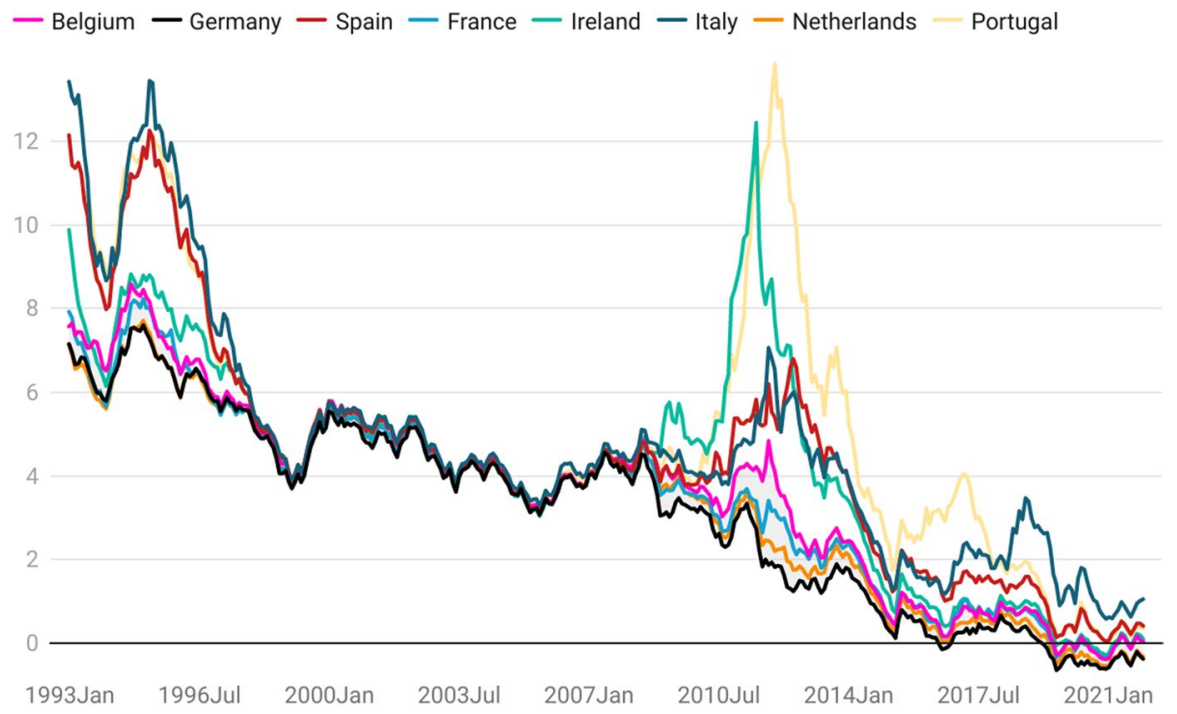

Fig. 1 Long-term bond yields for selected euro area countries

sovereign defaults in Europe simply appeared to be a very unlikely event to most market participants during the early years of the euro. As the prospect of persistent devaluations receded in the run-up to the euro and then (apparently) disappeared altogether with its introduction, bonds issued by countries with high levels of public debt became more attractive to investors. Yields on sovereign debt across all euro area member states-which had previously differed substantially-converged within a narrow band and remained this way until 2009. See Fig. 1 for the long-term sovereign bond rates of a selected group of euro area member states. ${ }^{4}$

The early years of the euro illustrated a positive version of the self-fulfilling dynamics that Sims had warned about. Reduced sovereign debt yields significantly helped to improve assessments of debt sustainability. For example, in 1995, Italy had a debt-GDP ratio of $119 \%$ and allocated $11 \%$ of its GDP to interest payments on public debt. In contrast, in 2007, with a debt-GDP ratio still standing at $104 \%$, Italy only spent $5 \%$ of its GDP on government debt interest. High debt ratios seemed more sustainable for as long as low risk premia were in place. ${ }^{5}$

In addition to the increased attractiveness of sovereign debt issued by the euro's 'peripheral countries', the elimination of devaluation risk increased the attractiveness of private sector lending to those countries for international investors. Interest rates on private sector debts declined in countries that had previously had high private sector interest rates because of devaluation risk premia. During the early

\footnotetext{
${ }^{4}$ Data taken from ECB Statistical Data Warehouse.

5 Data available from the European Commission's AMECO online database. Available at https://ec. europa.eu/info/business-economy-euro/indicators-statistics/economic-databases/macro-economic-datab ase-ameco/ameco-database_en
} 
2000s, large debt burdens were built up by firms and households in these countries, financed by capital inflows from investors in core countries, either via new bank deposits, bond market funding or the opening of new branches in these countries. At this time, this process of financial integration was widely praised as a major success of the introduction of the euro.

\section{Outright monetary transactions}

Here, we will discuss the events leading to the introduction of OMT, the rationale for the programme and its implications for fiscal policy in the euro area.

\subsection{The crisis of 2012}

The global financial crisis of 2008 brought an end to the calm that characterised the early years of the euro. The early months of the financial crisis in 2007, which began with concerns about US sub-prime mortgage-backed securities, saw comments from European politicians about how the crisis showed the weakness of 'Anglo-Saxon' financial models. However, it quickly became apparent that European banks had been voracious purchasers of these securities and that these banks had issued many loans of dubious quality themselves.

The crisis saw a reversal of the previous process of euro area financial integration. With banks around the world retrenching, countries in the euro area's periphery, such as Ireland and Spain, which had seen large inflows of private capital in the early years of the euro, experienced a 'sudden stop'. While the impact of this sudden stop on the banking sector was partially shielded by the ECB's move to providing fixed-rate full allotment loans to banks, the sharp turnaround in financial conditions meant these economies were plunged into deeper recessions than the rest of Europe and forced into large fiscal adjustments.

Developments in Greece began to concern financial markets in late 2009. Its reported pre-crisis deficits and debt ratios had already been relatively high. Then, the new government elected in October 2009 admitted the official figures were substantially understating the extent of Greek public debt. The 2009 deficit that had been reported as 5\% of GDP was revised up to $15.6 \%$ while the debt ratio for 2009 was revised up from 113 of GDP to $130 \%$. As soon as the true extent of its public debt problem became clear, financial markets became concerned that Greece could be heading for sovereign default. Yields on Greek sovereign bonds rose throughout late 2009 and early 2010, effectively locking Greece out of the debt markets.

The initial response to the Greek crisis from political leaders in the euro area was denial. The news stories of late 2009 and early 2010 reported plenty of reassurances that Greece would not need a bailout and would get its public finances back on track without a sovereign default. Rather than countenance a debt restructuring, the other euro area countries provided loans to Greece and economists discovered the no-bailout clause did not rule out bailouts. The ECB purchased Greek government bonds in its Securities Markets Programme (SMP) as part of an unsuccessful attempt to 
maintain market access for the Greek government and ECB officials were the strongest voices countenancing against a restructuring of Greek debt.

Ultimately, however, the reality of Greece's debt situation prevailed. With many private investors in Greek sovereign debt being paid off in 2010 and the IMF having a special preferred creditor status, it became clear to euro area leaders that without a restructuring of the remaining privately held bonds, they would be getting back very little of the money they were loaning to Greece. In October 2010, Angela Merkel and Nicolas Sarkozy took a walk on the beach at Deauville. Their meeting concluded with a short communique stating that any future crisis management regime would include 'the necessary arrangements for an adequate participation of private creditors'.

These words changed the euro area forever. Yields on Irish sovereign debt exploded, and within weeks, Ireland had applied for an EU-IMF bailout. Similarly, Portuguese yields also rose steadily until it applied for a bailout in May 2011. European governments and the leaders of its policy institutions continued to debate the wisdom of a Greek debt restructuring throughout this period but the die was effectively cast at Deauville and by July 2011, the euro area's leaders agreed that Greece's private sovereign debts should be restructured.

By summer 2012, markets were not simply worried about the possibility of sovereign defaults in a range of euro area countries. The theoretical scenario described above by Chris Sims in 1999 was playing out in reality. Markets were now deeply worried about potential 'redenomination risk' due to countries leaving the euro and introducing a new lower-valued currency. For many, the future of the euro itself was appeared to be at stake.

\subsection{OMT: its rationale and its implications}

On July 26, 2012, ECB President Mario Draghi gave a short speech in London at an investment conference. The speech contained the crucial words 'Within our mandate, the ECB is ready to do whatever it takes to preserve the euro. And believe me, it will be enough'. The speech was short on details about what exactly 'whatever it takes' would mean in practice, but it did focus on financial fragmentation and noted 'To the extent that the size of these sovereign premia hampers the functioning of the monetary policy transmission channel, they come within our mandate'.

The speech was followed up by the announcement a week later of a new monetary policy tool, Outright Monetary Transactions. The programme's stated aim was 'safeguarding an appropriate monetary policy transmission and the singleness of the monetary policy'. ${ }^{6}$ An OMT programme could intervene to purchase a specific country's sovereign bonds and lower its borrowing yields when the ECB judged these yields as excessively high. A triggering of the OMT programme would see the Eurosystem purchasing bonds with short maturities, particularly between 1 and 3 years, conditional on the country involved agreeing to a full or precautionary adjustment

\footnotetext{
${ }^{6}$ For evidence that the reversal of financial integration of this period had an impact in reducing the 'singleness' of monetary policy, see Gori (2018).
} 


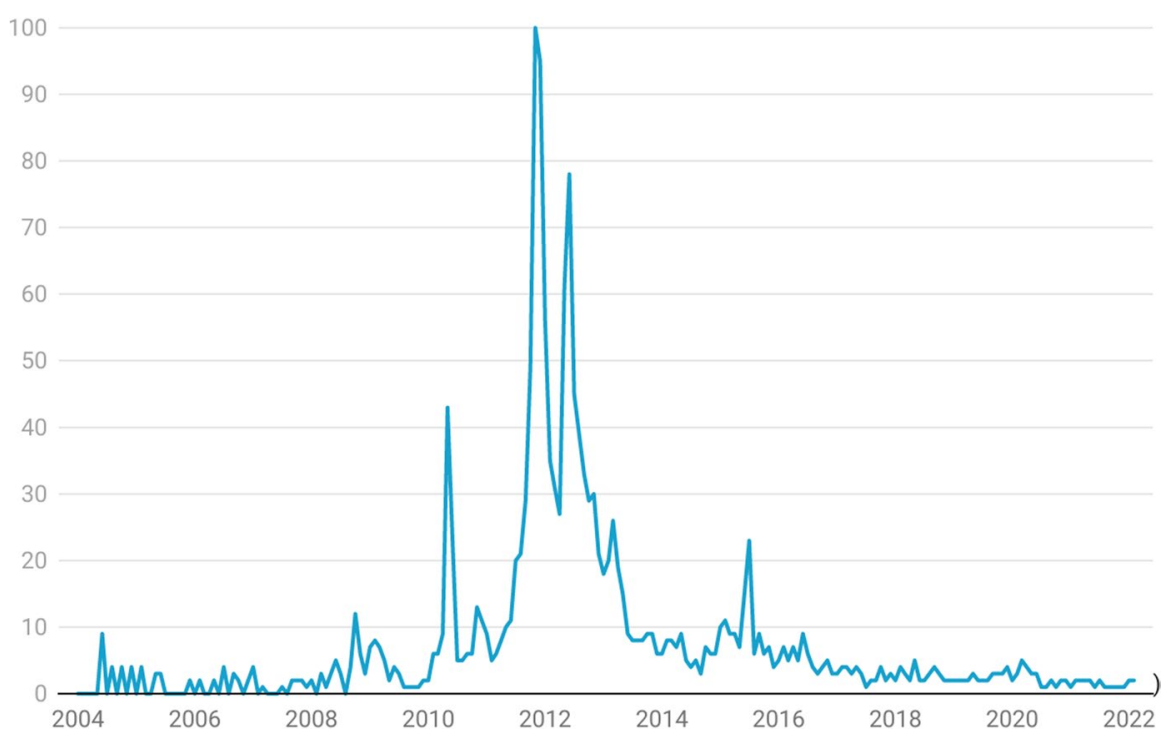

Fig. 2 Index of Google Searches for 'Euro Crisis' (peak value=100)

programme overseen by the European Stabilisation Mechanism (ESM) and the IMF. No quantitative limits to the size of OMT purchases would be announced. The Eurosystem accepted that its purchases under OMT would be given the same treatment as other creditors in the event of a debt restructuring.

This decision on creditor status contrasted with the ECB's behaviour in relation to the Greek government bonds that it had bought in 2010 as part of its Securities Markets Programme (SMP). When Greece's bonds were being restructured, the ECB refused to co-operate and instead they were issued new bonds with equal value to those they had purchased. In the 2015 Accorinti case at the European General Court brought against the ECB by private investors in the restructured Greek bonds, the ECB argued that it should not have to be treated equally to private creditors because the motivation for its intervention was based on the public good rather than private gain and because incurring losses on its bonds would undermine the independence enshrined in Article 130 of TFEU.

The General Court ruled in favour of the ECB in the Accorinti case, so it clearly had the right to assume a de facto senior creditor position should it wish to. However, if the ECB were to insist on this position, then losses for private sector bondholders would increase in any restructuring since the debt reduction would have to be spread across a smaller amount of bond holdings. In this case, the triggering of an OMT programme could make investors more concerned about holding a country's debt rather than less concerned. Mario Draghi acknowledged this in December 2014 when answering a question about future asset purchases by saying 'we don't want to cause unintended monetary policy tightening in choosing forms of seniority which would be counter-productive'?

$\overline{{ }^{7} \text { https://www.ecb.europa.eu/press/pressconf/2014/html/is141204.en.html }}$ 
Draghi's 'whatever it takes' speech, combined with the subsequent OMT announcement, was a hugely successful intervention. Without ever having to trigger the programme into action, the ECB changed the mood in financial markets. Faced with the prospect of a potentially limitless wall of money that ECB could invest to support sovereign bond prices, investors ceased betting that there were going to be further sovereign defaults. As shown in Fig. 1, sovereign bond yields began to converge after Draghi's speech and public concern about the euro's existential crisis eased. Figure 2 shows an index of Google searches for 'Euro Crisis' - it clearly marks out Summer 2012 as the point where interest in the crisis began to recede.

The Treaties limit the ECB's area of competence to monetary policy and so the stated rationale for introducing OMT is the need to maintain a single monetary policy across the euro area as mandated by Article 199 of TFEU. However, the policy has had implications that go well beyond monetary policy. Financial markets have interpreted the OMT as providing a 'backstop' for sovereign debt markets that greatly reduces the probability of self-fulfilling sovereign defaults. That this is a key purpose of OMT from the ECB's point of view is clear from ECB Executive Board member Isabel Schnabel's comments in a 2020 speech. An extended quote is worth providing:

financial markets are neither always rational, nor efficient. They can be prone to panic and instability. Acute periods of market stress can drive a considerable wedge between a country's cost of borrowing, as justified by economic fundamentals, and actual financial conditions, giving rise to self-fulling price spirals.

Such periods of turmoil - if left unaddressed - can quickly turn a liquidity crisis into a solvency crisis, giving rise to huge costs for society as a whole. Central banks are best placed to protect the public from such destabilising forces. In the euro area, the ECB can only be a lender of last resort to financial institutions. The Treaty explicitly prohibits monetary financing of public debt.

But the ECB can, and should, provide liquidity when the market fails to coordinate and when the risk absorption capacity of financial market participants is severely constrained. Central bank interventions quickly instil confidence and allow the market to coordinate on the "good" equilibrium once the initial fog of panic and fear has lifted.

So, while designated a monetary policy, the OMT announcement has also had profound fiscal implications. By lowering borrowing costs, it has made it easier for governments to cope with larger debt burdens. The programme has also reduced the importance of the assessment of market participants about sovereign debt sustainability. It could be argued that OMT sent a signal to financial markets that the ECB was willing, in a crisis, to substitute its own judgement for the market's judgement on what represents an appropriate sovereign bond yield.

\section{The ECB's sovereign bond purchases}

Here, we discuss the Eurosystem's sovereign bond purchase programmes and their fiscal impact. 


\subsection{Programme design}

While the OMT programme emerged as a special 'European solution to a European problem', the other major source of fiscal-monetary interactions, the asset purchase programmes, is quantitative easing $(\mathrm{QE})$ programmes of the type previously adopted in the USA and elsewhere.

Despite an extended period of recovery from the euro crisis after 2012, the ECB consistently failed to meet its target inflation rate of close to $2 \%$. With its key deposit rate already set at a negative value and limited room for further interest rate cuts, the ECB decided in January 2015 to start its own Asset Purchase Programme (APP). The programme began in earnest with a plan to purchase of $€ 60$ billion in securities a month from March 2015 until at least September 2016, so the plan was to purchase about $€ 1.1$ trillion in total, with the vast majority of the purchases being government bonds bought as part of its Public Sector Purchase Programme (PSPP).

Concerns about potential violations of various Treaty provisions, but most importantly the prohibition on monetary financing, had a clear influence on the design of the PSPP. ${ }^{8}$ The key features of the programme have been as follows.

Decentralised Perhaps with Article 125 in particular in mind, the purchases were decentralised to the NCBs, with each purchasing the sovereign bonds issued by their own country and an agreement that there would be no risk sharing, so a sovereign default in one country would not affect the balance sheet of the NCBs in other countries.

Capital key The bonds are purchased according to each country's ECB capital key — an average of their share in euro area GDP and population—so the programme does not purchase a disproportionate amount of bonds issued by high debt countries.

Market neutral Sovereign bond purchases have the same average maturity as the total amount in circulation, consistent with the idea of 'market neutrality'. This means it is the financial markets rather than the ECB that decides the average maturity of a member state's debts.

No short-term debt To avoid the appearance of the Eurosystem getting involved in providing short-term financing for governments, the 2015 announcement excluded all bonds with a remaining maturity under two years. This was later changed to 1 year.

Ratings Purchases were to be limited to bonds with credit ratings above a specified level. This had the effect of rendering Greek government bonds ineligible for the programme.

\footnotetext{
${ }^{8}$ See ECB (2015) for details on the initial design of the PSPP.
} 
Blackout period There is a minimum 'blackout period' after the issuing of a bond before the ECB will consider purchasing, thus ruling out financial institutions acting as a 'proxy' for the ECB in a primary debt auction. No details have been provided about the length of this period.

Creditor treatment As with OMT, the ECB indicated it would accept the same treatment as private creditors rather than insist it was a preferential creditor.

Purchase limits The ECB decided to limit the amount of bonds that it could purchase with the stated purpose being to 'allow for the smooth operation of markets in eligible marketable debt securities, and to avoid obstructing orderly debt restructurings'. These limits took the form of an issue share limit for specific bonds (initially set at $25 \%$ but changed in September 2015 to 33\%) and an issuer limit of $33 \%$ on the total amount that could be purchased from an individual sovereign (keeping in mind that some central banks already owned some government bonds prior to the PSPP). The issuer limit applied to all assets eligible for the programme with maturity greater than 1 year and less than 30 years.

The selection of $33 \%$ as a limit on the Eurosystem's holdings relates to the collective action clauses (CACs) which are part of all euro area sovereign bond issues since 2013. These clauses allow sovereign bonds to be restructured once agreement is reached with holders of two-thirds of the outstanding debt. While CACs had traditionally been applied on an issue-by-issue basis, the standard new 'Euro CAC' also allows sovereigns to trigger a full cross-series restructuring of all of their bonds.

This raises an issue in the case where the Eurosystem holds more than one-third of the outstanding debt of one of the member states. Agreement by the Eurosystem to having its debt restructured could be considered monetary financing. Indeed, despite insisting it will accept the same treatment as other creditors, the ECB has signalled to the ECJ that it will not vote to accept a restructuring of bonds subject to CACs. ${ }^{9}$ At the same time, the ECB (2015) noted in its PSPP announcement that it wished 'to avoid obstructing orderly debt restructurings' and so it would keep its holdings below the $33 \%$ limit.

These issuer limits have become increasingly relevant over time because the size of the Eurosystem's holdings of sovereign bonds has turned out to be much larger than originally envisaged in March 2015. The scale of purchases was adjusted upwards on several occasions after the initial announcement. The Eurosystem's portfolio of 'securities held for monetary policy purposes' reached about $€ 2.6$ trillion by the end of 2018 at which point the size of the portfolio was kept stable. Purchases began again at the slower pace of $€ 20$ billion per month in November 2019. The onset of the global pandemic saw the ECB introduce the Pandemic Emergency Purchase Programme (PEPP). Originally envisaged as a programme to purchase up to $€ 750$ billion in assets, this ceiling was subsequently raised to $€ 1.85$ trillion with a

\footnotetext{
9 See Grund and Grle (2016) for a detailed discussion of the implication of CACs for the Eurosystem's holdings of sovereign bonds.
} 


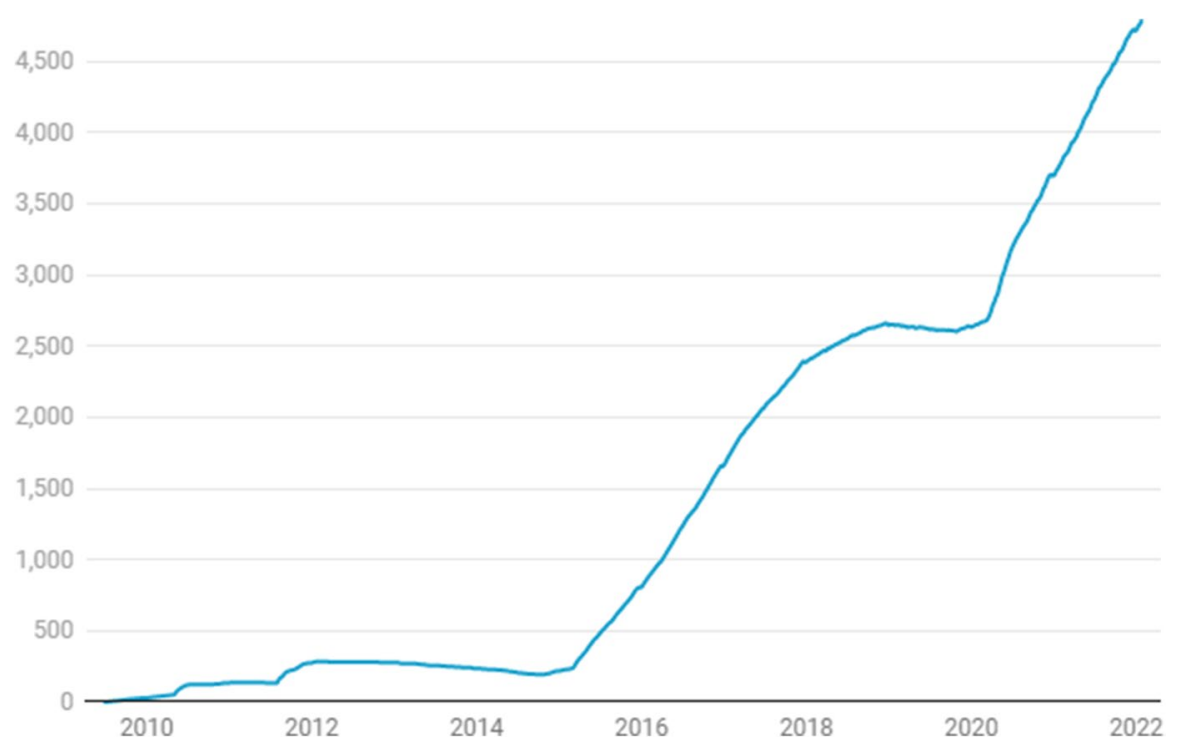

Fig. 3 Eurosystem securities held for monetary policy purposes (billions of euros)

waiver on credit quality introduced to allow for the purchase of Greek government bonds. See Fig. 3 for the total size of the Eurosystem's portfolio of 'securities held for monetary policy purposes'.

With the introduction of the PEPP, the ECB indicated that it was not necessarily going to keep to its previous policy of holding less than one-third of a member state's sovereign debt, stating 'To the extent that some self-imposed limits might hamper action that the ECB is required to take in order to fulfil its mandate, the Governing Council will consider revising them to the extent necessary to make its action proportionate to the risks that we face'.

To explain why the ECB's decided to consider waiving the issuer limits, note that by December 2021, the Eurosystem owned almost $€ 2.5$ trillion in sovereign bonds in its PSPP portfolio and an additional $€ 1.5$ trillion in its PEPP portfolio. ${ }^{10}$ To put that in perspective, the European Commission estimates that euro area gross government debt (GGD) was about $€ 12$ trillion by the end of 2021 .

At first look, these figures suggest the one-third issuer limit is being approached, at least on average. However, several caveats apply to this calculation. The GGD figures measure the face value of the debt. With falling yields, the market value of euro area sovereign bonds has increased in recent years, so the ECB's purchases may represent a smaller fraction of outstanding government debt than the above figures suggest. Conversely, the issuer limits apply only to bonds considered eligible for the

\footnotetext{
${ }^{10}$ Data on PSPP holdings are from https://www.ecb.europa.eu/mopo/implement/app/html/index.en.html and data on PEPP holdings are from https://www.ecb.europa.eu/mopo/implement/pepp/html/index.en. html.
} 
programme, so, for example, bonds with greater than 30 years maturity are included in the GGD but not in the total considered by ECB when assessing its issuer limit. A full calculation of the share of public debt owned by the ECB for various countries thus requires a detailed analysis and likely would require access to confidential data. However, it is reasonable to take from the ECB's announcement about the potential waiving of issuer limits that they anticipate potentially going over these limits with their PEPP purchases.

A final important feature of PSPP and PEPP and one that distinguishes them from OMT is that their implementation has been via a series of pre-announcements that specific amounts would be bought. Combined with the policy of market neutrality, this gives financial market participants a good idea of the likely extent of ECB purchases of specific types of bonds over the duration of the announced period.

\subsection{Rationale and fiscal impact}

As with the OMT programme, the ECB has been clear that its asset purchase programmes are a monetary policy aimed at influencing financing conditions. The channels through which QE affects the economy are still a subject for active debate in academic and central banking circles. Bernanke (2020) cites the proximate goal of QE as being to reduce long-term interest rates via two key channels: a 'portfolio balance' effect through which boosting demand for long-term bonds raises their prices and lowers yields and a 'signalling' effect by which asset purchases make forward guidance on keeping interest rates low more credible.

Bernanke famously joked 'The problem with QE is it works in practice but it doesn't work in theory'. ${ }^{11}$ The theory he was referring to was the idea that efficient markets and arbitraging investors should see all assets priced purely according to their expected risk and return. In such models, there is no 'demand curve' for sovereign bonds and purchases of bonds by a central bank should not have an impact on their yields. The empirical evidence favours Bernanke's position that QE programmes have worked in practice to reduce bond yields but while efficient market theories of bond pricing may not be perfect, they are also not wildly wrong. The evidence suggests that enormous central bank bond purchases have achieved relatively modest reductions in long-term yields. For example, Ihrig et al. (2018) concluded that the \$3.5 trillion spent in the Federal Reserve's QE programmes prior to the pandemic reduced term premia by about one percentage point. Studies by Eser et al. (2019) and Valiante (2017) suggest the Eurosystem's pre-pandemic sovereign bond purchases have had a similar effect.

While QE programmes are not motivated by a specific desire to reduce the debt burden on sovereigns or make it easier for countries to issue more debt, it cannot be ignored that these programmes have clear fiscal effects. The first fiscal impact is that lower bond yields reduce the cost of borrowing for governments. This allows governments to run larger debt levels for a given level of annual interest costs. A second

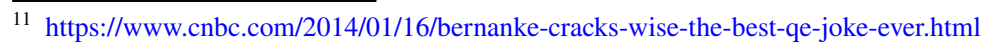


fiscal impact is that regular purchases of sovereign bonds by central banks increase liquidity in these markets and reduces the possibility of a default induced by a 'buyers strike'.

The third fiscal impact is that much of the interest earned on sovereign debt held by national central banks in the Eurosystem ends up being repaid to governments as part of their annual dividend from profits. These interest payments see the right hand of the public sector paying the left hand, which eventually passes it back. For as long as this debt is held by the national central bank, the underlying cost of interest on the debt is lower than the official 'gross' figure for interest payment and the effective gross government debt overstates the net debt owed to the private sector.

One caveat to this point is that the Eurosystem pays for its sovereign bond acquisitions via credits to the deposit accounts of that banks hold with NCBs and these accounts are interest-bearing liabilities. Viewed from a consolidated public balance sheet point of view, the public sector has merely swapped one form of debt to the private sector (government bonds) for another (deposit accounts that Eurosystem banks hold with the NCBs).

That said, the interest rate the Eurosystem pays on reserves is the bottom rate in its 'corridor' system, so the average yield on sovereign bonds is generally higher than the cost of remunerating the reserves created to allow these purchases. And the remuneration rate for deposits with the Eurosystem in recent years has been negative, although the effect of this on the Eurosystem's profits has been partially offset by the fact that some of the bonds being purchased have had negative yields and by the recently introduced 'tiering' policy. To summarise, the consideration of interest on reserves means we cannot completely discount the debt owned by NCBs as effectively interest-free but their ownership of sovereign bonds does reduce the net interest cost.

\section{The ECJ and Article 123}

Article 123 does not rule out secondary market purchases of sovereign bonds by the Eurosystem. However, the practical impact of the article depends on how it is interpreted by the EU's courts and in practice; the ECJ and national courts do not interpret European law in a literal way but in a purposive way. In other words, they consider what the original purpose of the legislation was rather than restricting themselves to precisely what the specific words say. ${ }^{12}$

For this reason, Article 123 can place limits on ECB's actions such as asset purchase programmes if the ECJ views these actions as running counter to what the article was intended to achieve. In this section, we discuss two important ECJ judgements-the Gauweiler judgement on OMT in 2015 and the Weiss judgement on

\footnotetext{
12 In legal scholarship, the 'purposive' approach is often termed the 'teleological approach'. For an authoritative discussion of the teleological approach taken by the ECJ, see Lenaerts and Gutiérrez-Fons (2013).
} 
PSPP in 2018 - and the implications these may have for limiting Eurosystem sovereign bond holdings in the future.

\subsection{The Gauweiler judgement}

The Gauweiler judgement of June 2015 stemmed from a request for a preliminary ruling from the German Constitutional Court of a case brought by multiple applicants against the ECB. The applicants claimed the ECB's OMT announcement exceeded its monetary policy mandate and violated Article 123 by interfering with market discipline on sovereign borrowers and via the potential for the Eurosystem to incur losses on purchases of poorly rated sovereign bonds. We will discuss four aspects of the case.

\subsubsection{Monetary policy mandate?}

On the first matter, the ECJ accepted the ECB's arguments that OMT is a monetary policy and thus falls within the ECB's authority. In particular, the Court noted that Article 119 of TFEU refers to the requirement that there be a single monetary policy in the euro area and accepted ECB's arguments that OMT's impact on sovereign bond markets acted to restore the 'singleness' of monetary policy. The Court noted that the Treaty did not define monetary policy and it was reasonable to give the ECB 'broad discretion' which instruments to deploy in pursuit of price stability.

\subsubsection{Monetary financing}

The ECJ also found that the OMT announcement was not inconsistent with Article 123 but their approval for future action under any OMT programme came with clear qualifications. Rather than accepting the ECB had the right to purchase as much sovereign debt on secondary markets as it saw fit, the Court argued that 'the aim of Article 123 TFEU is to encourage the Member States to follow a sound budgetary policy, not allowing monetary financing of public deficits or privileged access by public authorities to the financial markets to lead to excessively high levels of debt or excessive Member State deficits' (Paragraph 100). In judging the legality of an intervention in sovereign bond markets the Court argued that 'sufficient safeguards must be built into its intervention to ensure that the latter does not fall foul of the prohibition of monetary financing' (Paragraph 102).

Given this framework, the Court's approval of the OMT announcement was based on its expectation that 'sufficient safeguards' would be in place so the programme would not undermine incentives for the country whose bonds were being purchased to pursue a sound budgetary policy. One safeguard highlighted was the requirement that the member state involved had to agree to an ESM-supervised adjustment programme, making it unlikely that the stability in sovereign yields brought about by an OMT intervention would be used to promote additional deficit spending.

The Court also argued that the ECB's refusal to pre-announce the size and length of its OMT intervention would mean that those who purchased bonds at primary 
auctions from the member state undergoing the programme could have no guarantee that their bond would subsequently be purchased by the Eurosystem. This uncertainty would mean that the programme did not cross over the line into effectively providing a guarantee for primary issuance by governments, which is clearly at odds with the intentions behind Article 123. The Court took further encouragement from the ECB's statement during the proceedings that 'a minimum period is observed between the issue of a security on the primary market and its purchase on the secondary market', a feature of the programme that was not described in the original announcements.

\subsubsection{Market discipline}

It is worth noting two interesting aspects of the Gauweiler proceedings regarding the role played by financial markets for a country experiencing an OMT programme. The first is that the judgement states that OMT purchases will not occur until the programme country has recovered ongoing access to sovereign bond markets. Paragraph 116 states that ECB was 'limiting that programme to certain types of bonds issued only by those Member States which are undergoing a structural adjustment programme and which have access to the bond market again' and Paragraph 119 describes how the programme is 'providing only for the purchase of government bonds issued by Member States that have access to the bond market again'.

I do not believe this is an accurate description of how OMT is intended to work. The ECJ's interpretation likely stems from the following passage in the September 2012 announcement of the 'technical features' of OMT:

Outright Monetary Transactions will be considered for future cases of EFSF/

ESM macroeconomic adjustment programmes or precautionary programmes as specified above. They may also be considered for Member States currently under a macroeconomic adjustment programme when they will be regaining bond market access.

This section mentions bond market access but this is in reference to those countries that at the time of the announcement were then undergoing macroeconomic adjustment programmes (Greece, Ireland, Portugal and Spain). The announcement stated that ECB was not yet willing to trigger OMT purchases for those countries but that it would consider doing so when they were re-accessing bond market funding. This was an 'also' statement, not an 'only' statement. As it turned out, the ECB did not deem it necessary to activate purchases for these countries.

So, this was a very specific statement about a specific number of countries in 2012. As best I can tell, however, neither this statement nor any others by ECB officials have committed the ECB to delaying OMT purchases until there was evidence that the applicant countries had re-accessed the primary bond market. It is possible, of course, that the mere announcement that an OMT programme was being activated would be sufficient to re-open market access for countries that had previously been shut out. However, it is also possible (perhaps likely) that market participants would wait to see the size and nature of OMT purchases before making decisions about participating in primary bond auctions. Indeed, reliance on 
re-opening of market access for OMT purchases to happen would appear to open another self-fulfilling loop in which pessimism about the restoration of market access leads to OMT purchases not taking place which in turn has a negative effect on market sentiment and likely induces a debt restructuring.

A second point about the interaction between market discipline and OMT is that the ECJ's judgement did not go as far in stressing the role of financial markets as the report on this case provided to it by Advocate General Pedro Cruz Villalon. The AG's report concluded as follows: 'The OMT programme is compatible with Article 123(1) TFEU, provided that, in the event of the programme being implemented, the timing of its implementation is such as to permit the actual formation of a market price in respect of the government bonds'. There is a strong tension between this point of view and the perspective of Schnabel (2020) and others that OMT should be triggered at times when markets are forming what the ECB considered the 'wrong' price, so that a central bank intervention is required to 'nudge' the market to the prices the ECB considers to be correct.

\subsubsection{Sovereign default risk}

The other important issue discussed in the Gauweiler judgement was whether the purchase of sovereign debt perceived by markets to have a high risk of default constituted monetary financing. At a functional level, the creation of money by the Eurosystem to purchase bonds that are then written down in value has the same impact on fiscal policy as directly providing money to governments to write off their debts, which is what Article 123 was designed to prevent.

The judgement argued that the purchase of high-yielding sovereign debt did not necessarily constitute a violation of monetary financing. The Court argued that the purchase and sale of financial assets is an essential element of the implementation of monetary policy, allowed for by the Treaties, and these activities inevitably involve risk.

The Court also had no difficulty in accepting the ECB's decision in relation to being treated as a normal creditor, though the following observation (Paragraph 126) is important in relation to the debate about issuer limits:

Furthermore, although the lack of privileged creditor status may mean that the ECB is exposed to the risk of a debt cut decided upon by the other creditors of the Member State concerned, it must be stated that such a risk is inherent in a purchase of bonds on the secondary markets, an operation which was authorised by the authors of the Treaties, without being conditional upon the ECB having privileged creditor status.

The judgement does not contain any explicit discussion of whether the ECB can agree to have its debt restructured but the fact that it only mentions 'debt cuts decided by others' should probably be read to mean that the Court considers an agreement by an NCB to restructure its sovereign bond holdings to be a violation of Article 123. 


\subsection{The Weiss judgement}

The Weiss judgement of December 2018 also stemmed from a request for a preliminary ruling from the German Constitutional Court of a case brought by multiple applicants against the ECB. The applicants claimed that the PSPP went beyond the ECB's monetary policy mandate and violated the principle of proportionality. They also claimed the programme violated Article 123 in various ways via undermining sound budgetary policy by lowering borrowing costs, via the certainty about the scale of ongoing bond purchase, via the absence of information about the length of blackout periods between issuance and purchases, via the possibility of losses on bond investments and via the fact that ECB could make losses by purchasing negative yielding bonds.

The ECJ dismissed claims that PSPP did not constitute monetary policy or violated the principle of proportionality. The judgement echoed the Gauweiler judgement in emphasising the broad discretion that should be given to the ECB in deciding which instruments to deploy in pursuit of price stability. Moreover, they dismissed the idea that actions taken by the ECB could be considered fiscal policies just because one of their impacts is to lower the cost of sovereign borrowing.

On the question of monetary financing, the Weiss judgement again focused on the question of whether the policy undermined incentives to pursue sound budgetary policy. The Court cited several features of the programme that reassured it that the programme did not undermining sound budgeting. The temporary nature of the planned purchase programmes is mentioned three times in the judgement. It also mentions the fact that the purchases are in proportion to capital keys, thus ruling out the Eurosystem automatically buying more bonds from high-debt countries, which could act as an incentive for further debt issuance. The Court was not concerned about secondary market purchases at negative yields on the grounds that these were prices set by the market and represented the judgement that the bonds were extremely safe.

In relation to the role played by maintaining market discipline on governments, the judgement cited the requirement that bonds could only be purchased if they had a sufficiently high credit rating as encouraging governments to maintain sound budgetary policies. The Court acknowledged that, unlike OMT, markets would have much greater certainty about the timing and scale of bond purchases but argued there was still sufficient uncertainty that an individual investor purchasing a bond at a primary auction could not be certain the ECB would eventually purchase their bond. The existence of a 'blackout' period between issuance and purchase was again cited in relation to this issue.

The final element stressed by the Court was that the ECB's commitment to issuer limits was another factor ensuring that investors could not be sure the Eurosystem would purchase their bonds and that the limits maintained a primary role for financial markets in setting financing terms for sovereign debt funding. In addition, Paragraph 141 of the judgement stated:

as a result of the purchase limits per issue and per issuer set out in Article 5(1) and (2) of that decision, in every case only a minority of the bonds issued by 
a Member State can be purchased by the ESCB under the PSPP, which means that that Member State has to rely chiefly on the markets to finance its budget deficit.

So what exactly is the ECJ's position on issuer limits? The Weiss judgement cited the one-third limits approvingly but did not go as far as insisting that purchases above that level constituted monetary financing even though this would trigger the complex issue of how a debt restructuring would proceed in that case. However, the declaration that 'in every case only a minority of bonds can be purchased' could be interpreted as placing an effective upper limit of just below 50\% on Eurosystem ownership of sovereign debt.

\section{Issues for the future}

Here, we discuss some of the issues that may arise in relation to monetary financing in the future.

\subsection{Could a new case against ECB be successful?}

A lot has happened since the Weiss judgement in December 2018. The developments over this period have made it more likely that the ECJ could uphold future objections that the combination of PSPP and PEPP represents a violation of Article 123.

Four different aspects can be pointed towards which, taken together, suggest that much of the reassurance the ECJ took from previous safeguards is no longer applicable.

Temporary programmes While the Weiss judgement referred to the temporary nature of the asset purchases and the plan to subsequently sell the bonds as reassurance, these purchases no longer look so temporary. In December 2018, the Eurosystem had purchased about $€ 2.6$ trillion in assets but had stabilised the total size of its portfolio. The ECJ could interpret the asset purchases as a large but temporary programme that was likely to be reversed once there was a normalisation of economic condition. From the current perspective, the Eurosystem has been acquiring sovereign bonds for most of the past 6 years and the combined portfolio is now over $€ 4$ trillion with no indicative timeline on when these bonds will be sold. The fact that other central banks, such as the Federal Reserve and Bank of England, did not fully sell off their sovereign bond portfolios acquired via $\mathrm{QE}$ also supports questioning the temporary nature of these investments.

Credit ratings $\mathrm{By}$ waiving the credit rating requirement so that it could purchase Greek bonds as part of PEPP, the ECB has taken away one of the safeguards that had been discussed in the Weiss judgement.

Budgetary developments The PEPP was introduced during a period when the global pandemic caused debt and deficit levels to rise all across the euro area. Some 
euro area member states are now at all-time high levels of debt to GDP and future applicants could argue that this represents unsound budgetary policy and that these fiscal policies were facilitated by the PEPP.

Of course, the ECJ has never explicitly defined the meaning of 'sound budgetary policies'. However, if it were to define that concept as relating to compliance with movement towards the reference values for debt and deficits in the European Treaties, then the current fiscal positions of many euro area members could be considered unsound. An alternative approach would be to examine the burden of the debt in relation to the ratio of debt interest payments to GDP. These are at far lower levels and do not currently indicate any sustainability problem. With Treaty change reforming the fiscal rules likely to be difficult to achieve, this raises the question of whether the European Commission could perhaps provide new guidance on the meaning of sound budgetary policies that relies less on arbitrary reference values and more on the underlying debt burden.

Issuer limits Perhaps the most important point is that the ECJ can no longer take comfort that the ECB is applying explicit limits to the size of sovereign bond purchases. Given the prominence given to these limits in the Weiss judgement, the decision to potentially waive them could be the single biggest change since December 2018 that could produce a different decision in future litigation.

\subsection{Implications of issuer limits for OMT}

What would be the implications of a future ruling by ECJ that the Eurosystem must keep its ownership share of sovereign bond holdings below a specific threshold fraction to avoid violating Article 123?

Consider the case in which the ECJ declares holdings above the one-third threshold to be illegal. In cases where an NCB owned more than one-third of its country's sovereign debt, it is likely the ECB Governing Council would have to set out a plan to reduce these holdings below the one-third threshold, most likely doing so in a gradual fashion to alleviate financial stability concerns.

Where would this leave the possibility of an OMT intervention?

If the NCB has made a legal commitment to make progress towards getting below a specific issuer share, then any bond purchases under an OMT intervention would need to be offset by larger sales. Other complicating factors include the commitment to focus OMT purchases on debt with maturity between 1 and 3 years and the possibility that ECJ could also require adherence to issue-specific limits of one-third. These considerations would severely limit the quantity of bonds the Eurosystem could buy.

If financial markets knew the relevant NCB had to reduce its total holdings, they would be less likely to view an OMT programme as the 'game changer' it was perceived to be in 2012. The big bazooka would be revealed to be a pea shooter. It is possible that the ECB's commitment to maintain low short-term rates for a long time could keep sovereign yields low and the current positive sentiment about debt 
sustainability could be maintained. But in the absence of the possibility of a largescale and effective OMT intervention, a self-fulfilling crisis ending in sovereign default could again become a possibility.

This possibility raises the question of what would happen to NCB bond holdings above the one-third threshold if the failure to rollover existing debt triggered the need for a full sovereign debt restructuring. The NCB could not agree to a CACdriven restructuring but it could decide to rapidly sell off its holding to get below the one-third threshold. With a debt restructuring looming, the NCB would likely incur large losses. The ultimate outcome would be that the NCB ended up losing some of (or possibly more than) their capital while central government obtains a debt writedown-precisely the kind of scenario the applicants in the Weiss and Gauweiler cases had argued would represent monetary financing.

Alternatively, it may turn out that CACs are not the mechanism employed by future euro area governments to restructure debt. ${ }^{13}$ For example, the Greek government restructured its debt via a unilateral act of the Greek parliament, and this may be the approach taken by future European governments when defaulting on debt. However, the ECJ could consider the inclusion of the NCBs debt holdings in a legislated debt write-down as a violation of Article 123 by the national government. This raises the spectre of a quick legislated write-down of sovereign debt that maintained the Eurosystem's preferred creditor status and relied on heavier losses for private investors.

An ECJ decision to instead insist on an issuer limit of 50\% is less likely to trigger the complications just described but it could still be problematic. It is possible that Eurosystem holdings of the sovereign debt of some of the more indebted countries could rise above $50 \%$ in the coming years, thus repeating the scenario just described. But even if holdings are below 50\%, the possibility of the effectiveness of OMT being limited remains.

For example, if an NCB holds $40 \%$ of a sovereign's debt and if financial markets were aware of the approximate current level of holdings (admittedly, there is limited transparency around these figures), then this will put an upper limit on the perceived size of any potential OMT intervention. This would be in direct contradiction to the intention that OMT should be seen as having no quantitative limit and with Draghi's assurance that 'believe me, it will be enough'. This would have the potential to trigger the same kind of reversal of sentiment just described for the case in which the $\mathrm{NCB}$ is above the required legal issuer limit.

\subsection{A QE versus OMT trade-off for ECB?}

What should the ECB do in response to these potential problems? One approach is to ignore them. There may not be another case before the ECJ for years and, despite their previous concerns about the need for safeguards, it is possible the Court may continue to find ways of considering the ECB's actions to still be legal.

\footnotetext{
13 See Gelpern and Gulati (2013) for a sceptical discussion of euro area CACs from two of the leading academic experts on sovereign debt law.
} 
I am not sure this approach would be wise. An alternative approach would be to announce a programme of gradual reductions in the Eurosystem's sovereign debt holdings aimed at bringing each NCB's holdings well below the one-third threshold. This policy could be consistent with a planned overall tightening of monetary policy but it is also possible that it could lead to an unwelcome increase in financing costs in the euro area. The empirical evidence on the impacts of QE programmes, however, suggests their impact on financing costs is modest and they are likely subject to diminishing returns. The ECB likely has enough other tools in its armoury to execute a gradual sell off in its sovereign bond portfolio in the coming years while maintaining financial stability.

In contrast, the scenarios envisaged above in which the OMT programme is either weakened or essentially ruled out have the potential to lead to a far greater financial stability problems. The Eurosystem handled the Greek sovereign default with minimal knock-on financial stability problems but we have no idea whether the same would be true of a future sovereign default in a large euro area member. In the hierarchy of important policy tools, retaining the need to do "whatever it takes' should take priority over a programme that achieves a relatively small reduction in financing costs.

Funding Open Access funding provided by the IReL Consortium.

Open Access This article is licensed under a Creative Commons Attribution 4.0 International License, which permits use, sharing, adaptation, distribution and reproduction in any medium or format, as long as you give appropriate credit to the original author(s) and the source, provide a link to the Creative Commons licence, and indicate if changes were made. The images or other third party material in this article are included in the article's Creative Commons licence, unless indicated otherwise in a credit line to the material. If material is not included in the article's Creative Commons licence and your intended use is not permitted by statutory regulation or exceeds the permitted use, you will need to obtain permission directly from the copyright holder. To view a copy of this licence, visit http://creativecommons.org/licen ses/by/4.0/.

\section{References}

Aguiar M, Chatterjee S, Cole H, Stangebye Z (2020) Self-Fulfilling Debt Crises, Revisited. Federal Reserve Bank of Philadelphia, Working Paper 20-03

Bernanke B (2020) The new tools of monetary policy. Am Econ Rev 110(4):943-983

Cohen D, Villemot S (2015) Endogenous debt crises. J Int Money Financ 51:337-369

Cole H, Kehoe P (2000) Self-fulfilling debt crises. Rev Econ Stud 67:91-116

Corsetti G, Dedola L (2016) The mystery of the printing press: monetary policy and self-fulfilling debt crises. J Eur Econ Assoc 14:1329-1371

Eser F, Lemke W, Nyholm K, Radde S, Vladu AL (2019) Tracing the Impact of the ECB's Asset Purchase Programme on the Yield Curve. ECB Working Paper number 2293

European Central Bank (2015). Decision 2015/774 of the European Central Bank of 4 March 2015 on a secondary markets public sector asset purchase programme. Available at https://eur-lex.europa. eu/legal-content/EN/TXT/PDF/?uri=CELEX:32015D0010\&from=EN. Accessed 1 Mar 2022

Gelpern A, Gulati M (2013) The wonder-clause. J Comp Econ 41:367-385

Goodhart C (1998) The two concepts of money: implications for the analysis of optimal currency areas. Eur J Polit Econ 14:407-432 
Gori F (2018) Banking integration and monetary policy fragmentation in the Eurozone. Int Econ Econ Policy 15:131-157

Grund S, Grle F (2016) The European Central Bank's Public Sector Purchase Programme (PSPP), the Prohibition of Monetary Financing and Sovereign Debt Restructuring Scenarios. Eur Law Rev 41:781-803

Ihrig J, Klee E, Li C, Kachovec J (2018) Expectations about the Federal Reserve's balance sheet and the term structure of interest rates. Int J Cent Bank 14:341-390

Lenaerts K, Gutierrez-Fons JA (2013) To say what the law of the EU is: methods of Interpretation and the European Court of Justice. C J Eur Law 20:3-61

Reinhart C, Sbrancia MB (2015) The liquidation of government debt. Economic Policy 30:292-333

Reinhart C, Reinhart V, Rogoff K (2015) Dealing with debt. J Int Econ 86:543-555

Schnabel I (2020) The Shadow of Fiscal Dominance: Misconceptions, perceptions and perspectives. Speech available at https://www.ecb.europa.eu/press/key/date/2020/html/ecb.sp200911 ea32b d8bb3.en.html. Accessed 1 Mar 2022

Sims C (1999) The precarious Fiscal Foundations of EMU. De Economist 147:415-436

Valiante D (2017) The 'Visible Hand' of the ECB's first quantitative easing. IEEP 14:601-624

Whelan K (2013) Sovereign default and the euro. Oxf Rev Econ Policy 29:478-501

Publisher's note Springer Nature remains neutral with regard to jurisdictional claims in published maps and institutional affiliations. 